\title{
Implementing International Engineering Programs
}

\author{
Ravi Jain \\ University of Cincinnati
}

Many engineering colleges are augmenting traditional rigorous technical training with education related to: foreign languages, study of other cultures and internship or living experiences abroad. These programs are often referred to as International Engineering Programs. A research study conducted indicates that at least 23 universities in the U.S. and Canada have significant international engineering programs (Saikali and Jain, 1996). The study provides a synopsis of the key features of each program surveyed and comparisons among the programs (See Table 1). To focus on the objectives and goals of establishing an international engineering program, it is important to understand the need in a global context.

Clearly, the United States of America is entering a "new world order" without its customary leadership in technology, industry, and economy. The changing international role of this country demands that leaders of educational institutions ensure that their graduates have adequate knowledge of global issues (Smickler and Sommers, 1989).

In a modern global economy, international trade is essential for continued economic growth of a nation. Figure 1 illustrates the tremendous growth (in dollars) of the international market for U.S. goods; U.S. exports more than doubled between 1987 to 1994. This is indeed an era of international interdependence and increased competition. Thus, new leaders must understand these issues and possess global perspectives. Regarding the engineering profession, these concerns dictate an increased need for individuals not only with strong technical backgrounds, but also with the ability to function and flourish in multi-cultural, competitive, global environments.

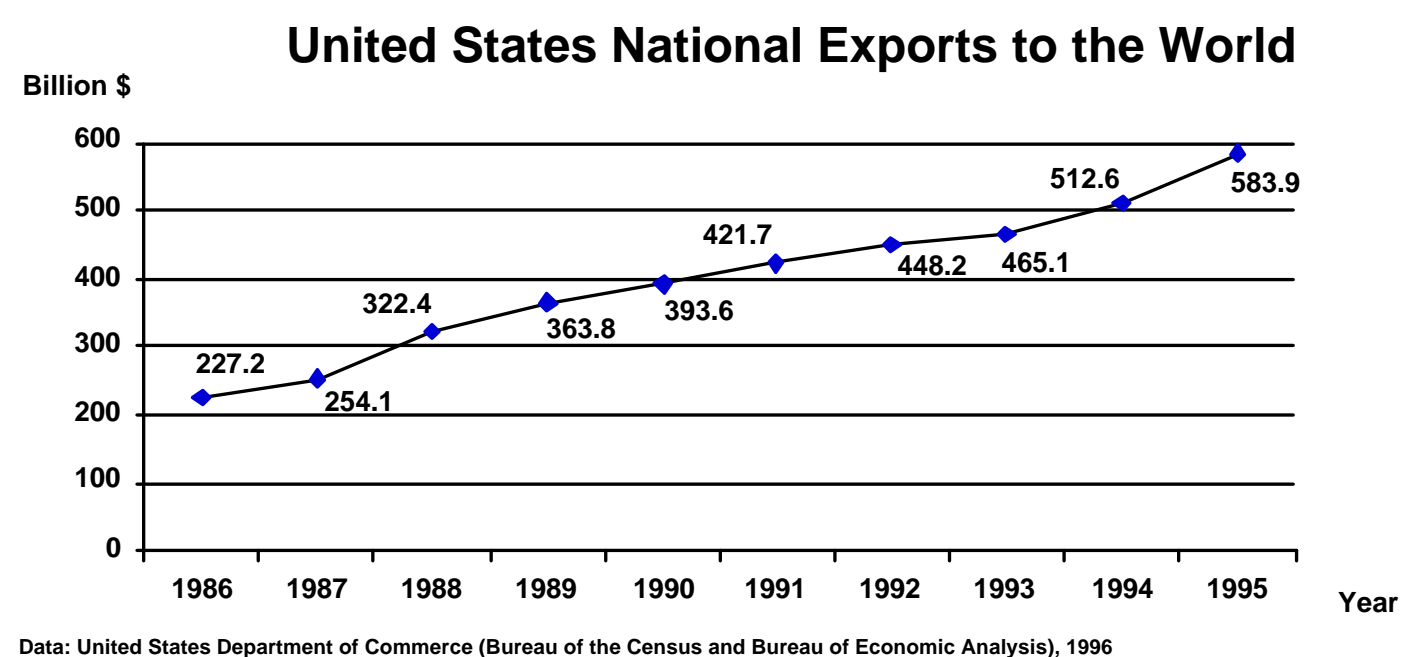

Data: United States Department of Commerce (Bureau of the Census and Bureau of Economic Analysis), 1996 Source: Council of Economic Advisors, 1996

Figure 1 


\begin{tabular}{|c|c|c|c|c|c|c|c|c|c|c|}
\hline $\begin{array}{l}\text { SPECIFICS / FEATURES } \\
\text { INSTITUTION / } \\
\text { PROGRAM }\end{array}$ & \begin{tabular}{|l|} 
Info \\
on \\
Int'1 \\
Prog at \\
www \\
Site \\
\end{tabular} & $\begin{array}{l}\text { J } \\
\text { A } \\
\text { P } \\
\text { A } \\
\text { N }\end{array}$ & $\begin{array}{c}\mathrm{G} \\
\mathrm{E} \\
\mathrm{R} \\
\mathbf{M} \\
\mathrm{A} \\
\mathbf{N} \\
\mathbf{Y}\end{array}$ & $\begin{array}{l}\mathbf{F} \\
\mathbf{R} \\
\mathrm{A} \\
\mathbf{N} \\
\mathrm{C} \\
\mathrm{E}\end{array}$ & $\begin{array}{l}\mathrm{U} \\
\mathrm{K}\end{array}$ & $\begin{array}{c}\mathrm{O} \\
\mathrm{T} \\
\mathbf{H} \\
\mathrm{E} \\
\mathbf{R}\end{array}$ & $\begin{array}{l}\text { Lang- } \\
\text { uage } \\
\text { Study } \\
\text { Req. }\end{array}$ & $\begin{array}{l}\text { Work } \\
\text { Abroad } \\
\text { Avail- } \\
\text { able }\end{array}$ & \begin{tabular}{|l} 
Study \\
Abroad \\
Avail- \\
able
\end{tabular} & \begin{tabular}{|l}
$(\mathrm{U})$ \\
Under- \\
graduate \\
(G) \\
Graduate \\
(O) Other
\end{tabular} \\
\hline Clemson University & $x$ & $x$ & $x$ & $\bar{x}$ & & $x$ & $x$ & $x$ & $\bar{x}$ & $\bar{U}$ \\
\hline Co-op Japan & $x$ & $x$ & & & & & $x$ & $x$ & & $\mathrm{U}, \mathrm{G}$ \\
\hline $\begin{array}{l}\text { Colorado School of } \\
\text { Mines }\end{array}$ & $x$ & & $x$ & $x$ & $x$ & $x$ & $x$ & & $x$ & $\mathrm{U}$ \\
\hline Drexel University & & $x$ & & & & & $x$ & $x$ & & $\mathrm{U}$ \\
\hline $\begin{array}{l}\text { GMI Engineering \& } \\
\text { Management Institute }\end{array}$ & & & $x$ & $x$ & $x$ & $x$ & & $x$ & $x$ & $\mathrm{U}$ \\
\hline $\begin{array}{l}\text { Global Engineering } \\
\text { Education Exchange }\end{array}$ & $x$ & & $x$ & $x$ & $x$ & $x$ & $x$ & $x$ & $x$ & $\mathrm{U}$ \\
\hline $\begin{array}{l}\text { Massachusetts Institute } \\
\text { of Technology }\end{array}$ & $x$ & $x$ & & & & & $x$ & $x$ & & $\mathrm{U}, \mathrm{G}, \mathrm{O}$ \\
\hline $\begin{array}{l}\text { Michigan State } \\
\text { University }\end{array}$ & $x$ & & $x$ & & $x$ & $x$ & & & $x$ & $\mathrm{U}$ \\
\hline $\begin{array}{l}\text { Ohio Northern } \\
\text { University }\end{array}$ & $x$ & & $x$ & & & & $x$ & $x$ & $x$ & $\mathrm{U}$ \\
\hline $\begin{array}{l}\text { Rose-Hulman Institute } \\
\text { of Technology }\end{array}$ & & $x$ & $x$ & & & $x$ & $x$ & $x$ & $x$ & $\mathrm{U}$ \\
\hline Syracuse University & $x$ & & & $x$ & $x$ & $x$ & & & $x$ & $\mathrm{U}$ \\
\hline University of Calgary & & & & & & $x$ & $x$ & $x$ & & $G$ \\
\hline University of Cincinnati & $x$ & $x$ & $x$ & & & & $x$ & $x$ & & $\mathrm{U}$ \\
\hline $\begin{array}{l}\text { University of Illinois } \\
\text { (Urbana-Champaign) }\end{array}$ & $x$ & $x$ & $x$ & $x$ & & $x$ & $x$ & $x$ & $x$ & $\mathrm{U}$ \\
\hline $\begin{array}{l}\text { University of Maryland } \\
\text { (College Park) }\end{array}$ & $x$ & $x$ & $x$ & $x$ & $x$ & $x$ & $x$ & $x$ & $x$ & $\mathrm{U}$ \\
\hline $\begin{array}{l}\text { University of Michigan } \\
\text { (Ann Arbor) }\end{array}$ & & $x$ & & & & & $x$ & $x$ & $x$ & $\mathrm{U}, \mathrm{G}$ \\
\hline $\begin{array}{l}\text { University of Notre } \\
\text { Dame }\end{array}$ & $x$ & & & & $x$ & & & & $x$ & $\mathrm{U}$ \\
\hline University of Pittsburgh & $\times$ & $x$ & & & & & $\times$ & $\times$ & $x$ & $\mathrm{U}, \mathrm{G}, \mathrm{O}$ \\
\hline $\begin{array}{l}\text { University of Rhode } \\
\text { Island }\end{array}$ & $x$ & & $x$ & $x$ & & & $x$ & $x$ & & $\mathrm{U}$ \\
\hline \begin{tabular}{|l|} 
University of \\
Washington
\end{tabular} & $x$ & $x$ & & & & & $x$ & $x$ & & $\mathrm{U}, \mathrm{G}, \mathrm{O}$ \\
\hline University of Waterloo & $x$ & $x$ & $x$ & $x$ & $x$ & $x$ & $x$ & $x$ & $x$ & $\mathrm{U}, \mathrm{G}$ \\
\hline $\begin{array}{l}\text { University of Wisconsin } \\
\text { (Madison) }\end{array}$ & $x$ & $x$ & $x$ & $x$ & $x$ & $x$ & $x$ & $x$ & $x$ & $\mathrm{U}$ \\
\hline Vanderbilt University & $x$ & $x$ & & & & & $x$ & $x$ & & $\mathrm{U}$ \\
\hline
\end{tabular}

Table 1

Comparison of International Engineering Programs 
The role of a university is to respond to crucial societal needs. Engineering today is practiced in an international environment and, therefore, increasingly subject to international competition (Pang, 1989). The University of Cincinnati's College of Engineering, with strong support from the University President, undertook activities to fully develop, implement, and institutionalize an international program that included appropriate language, culture, and history training, a design clinic with international perspective, and a five-month internship experience either in Japan or Germany. These countries were chosen because of their importance to U.S. foreign trade and their acknowledged technological leadership in science and engineering.

The origins of the College of Engineering's International Engineering Program (IEP) could be traced to the tradition of innovation at the University of Cincinnati (UC). As an example, cooperative education (co-op) was established here in 1906. It was the first such educational program in the nation. Since then, co-op education at the College of Engineering has become the largest mandatory program of any public engineering school in the country. The IEP was just another undertaking in the innovative spirit of co-op education. Since the co-op engineering curriculum is quite structured, adding language and culture training and still meeting the requisite $\mathrm{ABET}$ and co-op requirements provided numerous challenges. The paper discusses:

- $\quad$ Overall IEP objectives and specific objectives resulting from a grant from the Fund for the Improvement of Posed Secondary Education (FIPSE) of the U.S. Department of Education.

- Main components of the IEP at the College of Engineering, University of Cincinnati

- $\quad$ Boundary conditions for implementing the program

- $\quad$ Student recruitment

- $\quad$ Course development

- International Design Clinic

- $\quad$ Overall evaluation of IEP implementation

- Student recruitment

- Course evaluations

- Design Clinic

- Co-op (internship) experience

- Critical issues for continued program success

All of these items are discussed in detail and a summary of findings from implementing the International Engineering Program is provided.

\section{Program Objectives}

The overall objectives of the IEP are:

1. Prepare young engineers for careers in the global market, who are:

- $\quad$ Technically competent

- $\quad$ Good cross-cultural communicators

- $\quad$ Sensitive to other cultures

- $\quad$ Possess good second language skills

2. Help enhance America's global competitiveness 
3. Attract talented students to engineering

4. Create a time-efficient and adaptable curriculum

5. Provide challenging and exciting opportunities for top students

6. Establish research collaborations and faculty exchanges (visiting scholars) with international institutions

7. Foster industrial liaison and development activities with international corporations

FIPSE provided a grant to the College of Engineering, University of Cincinnati, to develop and enhance the IEP. Specific objectives of the project funded by FIPSE were:

- To fully develop, implement, and institutionalize a unique IEP

- To develop curriculum and implement language and culture training programs with a focus on German and Japanese

- To train engineers to have a global perspective

\section{Main Components of the IEP}

- Introduction to International Engineering (1 unit course)

- Intensive language and culture courses (approximately 300 classroom hours)

- Humanities and social sciences courses (four in total) related to history, international relations, or management styles specifically focusing on Japan or Germany

- $\quad$ Approximately five-month internship (co-op work experience) either in Japan or Germany

- $\quad$ Design Clinic with a focus on international issues

This basic undergraduate program is being augmented with research collaboration, graduate students, visiting scholars, faculty exchanges and major industrial liaison activities all with a global focus. This paper covers only the main components of the undergraduate program. Figure 2 shows the overall program and course schedule. 
UNIVERSITY OF CINCINNATI

INTERNATIONAL ENGINEERING PROGRAM SCHEDULE

\begin{tabular}{|c|c|c|c|c|}
\hline YEAR & AUTUMN & WINTER & SPRING & SUMMER \\
\hline Freshman & Classes & Classes & Classes & Off \\
\hline
\end{tabular}

Apply to IEP

\begin{tabular}{|c|c|c|c|c|}
\hline Sophomore & Classes & 1st Co-Op & Classes & 2nd Co-Op \\
\hline
\end{tabular}

Intro. to Int'l.

Eng. Course

\begin{tabular}{|c|l|l|r|}
\hline Pre-Junior & 3rd Co-Op & Classes & 4th Co-Op \\
\hline $\begin{array}{l}\text { 1st H \& S } \\
\text { Elective }\end{array}$ & $\begin{array}{l}\text { 2nd H \& S } \\
\text { Elective }\end{array}$ & $\begin{array}{r}\text { Intensive } \\
\text { Language/ } \\
\text { Culture Course } \\
\text { (6 weeks) }\end{array}$
\end{tabular}

Junior

\begin{tabular}{|c|c|c|l|}
\hline Classes & Classes & & 5th and 6th Co-Op Overseas \\
\hline
\end{tabular}

$\begin{array}{lll}\begin{array}{ll}\text { 3rd H \& S } \\ \text { Elective }\end{array} & \begin{array}{l}\text { th H \& S } \\ \text { Elective }\end{array} & \begin{array}{l}\text { Workplace } \\ \text { Intensive } \\ \text { Language }\end{array} \\ \text { Language } & \text { Maintenance } & \text { (2-4 weeks) }\end{array}$

Senior

\begin{tabular}{|l|l|l|l|}
\hline Classes & Classes & Classes & \\
\hline
\end{tabular}

Optional International Design Clinic

Figure 2 


\section{Boundary Conditions}

The following boundary conditions were established for the program:

- $\quad$ Minimize added costs to students

- $\quad$ Participants to complete degree in same time (5 years) as other students

- Meet technical requirements for normal engineering curricula

- $\quad$ Fully meet ABET criteria

- $\quad$ Comply with UC co-op requirements

- $\quad$ Participants to develop significant second language and cross-cultural skills

- $\quad$ Prepare students for overseas work experience

- Include an overseas working and living experience

\section{Student Recruitment}

IEP recruitment activities include informational meetings (two each year) at UC for high school counselors and teachers, mailing brochures to all students who apply for admission to the college, announcements to the German community through the Goethe Institute and the UC Germanic Languages and Literature Department, and informational meetings with the freshman class (one early in autumn quarter and one at the start of spring quarter). In addition, mailing of more than 600 pieces is done in January of each year, and a general IEP brochure is sent to all students offered admission to the College of Engineering. This brochure has a return portion for students interested in receiving more information about the IEP.

Details about the IEP are also included in a new information video from the College of Engineering. This video is used for recruiting purposes in high schools throughout the area.

The grade point average (GPA) for admission to the IEP has been set at 3.0 (out of 4.0). Some students with a GPA less than 3.0, but possessing exceptional capabilities and potential, may be admitted on a provisional basis.

An informational meeting is held in March of each year for all freshmen. Applications are completed at that time, and determination of acceptance into the program is made by May. Acceptance is based on academic achievement and student interest in international education. Academic standards for admission are clearly advertised and emphasized, and students with less than the standard generally do not apply. By working with faculty advisors, special efforts are made to recruit women and minority students.

\section{Course Development}

The following courses were developed for the program.

1. Introduction to International Engineering is a course designed to provide IEP students with sufficient information about Germany and Japan in order to make intelligent decisions about their focus. 
2. Intensive Japanese Language/Culture I meets 7 hours per day for 6 weeks, beginning the first day of the third term during summer quarter (on or about August 8).

3. Intensive Japanese Language/Culture II continues to build and maintain skills learned in the summer course. Meets 3 hours per week fall quarter.

4. Intensive Japanese Language/Culture III continues to build on previous Japanese Language and Culture courses. This course consists of two parts: 1) 3 hours per week winter quarter and 2) intensive course of approximately 70 hours ( 7 hours per day for 2 weeks) beginning the first day of classes spring quarter before going overseas.

5. Intensive German Language/Culture meets 7 hours per day for 6 weeks, beginning the first day of the third term during summer quarter (on or about August 8).

6. Two new courses, German Speaking World I and II, were developed and taught partially in German during the autumn and winter quarters. These courses are designed not only for language maintenance but also for further learning about German and European culture, geography, and peoples. Conducting these courses in German was a unique experience for students. It required considerable development and preparation on the part of the faculty.

IEP students have access to the necessary humanities and social sciences $(\mathbf{H \& S})$ courses conducted at other colleges in the University. The engineering curriculum has to meet rigorous ABET (Accreditation Board for Engineering and Technology) requirements for engineering, humanities, and social sciences courses. The IEP curriculum had to be tailored to meet these constraints. One course, Japanese Management Style, was also made available to students focusing on Japan.

\section{International Design Clinic}

International Design Clinic conducted design programs with an international perspective. Clearly, in this global market, manufacturers cannot afford to ignore the revenue potential of foreign markets, the necessity of competing abroad to protect domestic share, or the advantages of learning the demands of customers in diverse markets. Consequently, a design clinic with an international focus is an important undertaking. The International Design Clinic included both technical and entrepreneurial aspects.

\section{Evaluation of IEP Implementation}

Clearly, evaluation is a critical part of any project. Major activities undertaken in the project were evaluated. These activities were designed to support the three main objectives of the project. Thus, major activity evaluation provides a means of determining the degree to which the project fulfilled its objectives. 


\section{Recruitment}

The IEP has served as a positive force in encouraging students to undertake engineering programs. Different activities undertaken for this purpose were described earlier. An analysis of incoming IEP students was conducted.

Applications received for the IEP indicate that 42 percent were aware of the program prior to choosing UC. Verbal conversations with students indicated that the IEP was one of the most important factors in their selection of the University of Cincinnati, College of Engineering.

Recruitment of women has been extremely successful; recruitment of minorities has not. We are working with the Assistant Dean of Emerging Ethnic Engineering $\left(\mathrm{E}^{3}\right)$ Program to develop mechanisms to encourage minority students to participate in the program. Although the College of Engineering expends considerable resources for language training, as well as provides travel stipends for students in need, there are some additional costs incurred by students in the form of one shortened co-op quarter to accommodate the language training, and reduced co-op salaries during the two quarters overseas. Most students in the College of Engineering rely on their co-op salaries to fund their schooling. For minority students, the financial burden is often greater. Working with the Assistant Dean and Director of the $\mathrm{E}^{3}$ Program, we hope to obtain funds to reduce the financial burden and, thereby, encourage minority students to participate in the IEP.

Professor John Grandin (University of Rhode Island) served as one of the external reviewers of the IEP and provided numerous thoughtful comments and suggestions. Conventional wisdom would suggest that requiring a certain GPA for a unique and demanding academic program is a good idea. His comments about the requirement that students must maintain a 3.0 or better GPA to remain in the IEP may be of particular interest to those institutions contemplating development of a similar program. Professor Grandin argued that academic talent should not be the sole criterion for admission to the IEP. The most intelligent student can still fail in a new cultural environment, whereas an average student with the proper attitude might succeed in ways totally unforeseen according to the traditional academic yardstick. Reasonable criteria for admission could be:

- $\quad$ Eagerness to learn the language and culture of the chosen country and openness to new ideas and different perspectives. For example, students must be tolerant, flexible, and willing to take unfamiliar paths.

- An understanding of and commitment to the goals of the program. Students must be aware that they may well be professionally called upon to work collaboratively with persons from other societies representing other cultural perspectives. They should use their time overseas to both mature as engineers and grow in sensitivity and understanding of the foreign culture they are in.

- The ability to represent effectively the University and the United States through tact and diplomacy. Students must be willing to see themselves as ambassadors and accept their time abroad as a responsibility and not merely a time for their own personal benefit. The wrong disposition on the part of a student could easily convince a company not to 
receive any future American interns and to form generalized opinions of American behavior.

- The ability to work independently. Most internship supervisors provide assignments with reasonable direction but are often busy people with little time for hand holding.

- $\quad$ Assertiveness in seeking out personal relationships and activities independently. Other cultures often do not intrude on the privacy of others. Students who want contact with co-workers must be willing and able to take initiative. They should see daily interaction, both on professional and social levels, as an integral part of their learning experience.

\section{Course Evaluations}

While student evaluation of the Introduction to International Engineering course was high, students indicated an interest in making this a credit course. The course syllabus was changed to include substantive material related to engineering training and practice in Japan and Germany, challenges related to working in a competitive global market, and impact of engineering and technology on societal development in Japan and Germany.

Development of Intensive Japanese Language/Culture courses was a challenging task. Students had to learn three different character sets (hiragana, katakana, and kanji) and sufficient Japanese language to be able to function well in a Japanese industrial environment. At the completion of the first six-week program, student language proficiency was evaluated by two outside experts. Their analysis indicated that the course did not adequately prepare students in Japanese language and culture related to the work environment. Consequently, after further study and analysis, Japanese Language/Culture courses were significantly upgraded to respond to issues dealing with engineering and technical work environment, organization culture, and oral communication in the work environment. Language maintenance that is conducted during the autumn and winter quarters was also judged to be inadequate. The number of student/faculty contact hours was increased from 20 to 60, including provision of additional opportunities for students to interact with native language speakers.

A comprehensive evaluation of the German language training was also conducted. As a result of this analysis and input received from the CDG (formerly known as Carl Duisberg Gesellschaft) in Cologne and co-op employers in Germany, students' spoken German language proficiency was identified as deficient. Classroom instructions were modified to address this need, and a new program of weekly German conversational meetings was initiated. These meetings included IEP students, other native German-speaking University students, and IEP faculty.

\section{Design Clinic}

A Design Clinic with a focus on international issues was conducted as described earlier. An evaluation of clinic activities indicates that international perspectives are now incorporated in a pervasive manner in the entire design clinic series. As a result, it is expected that not only the IEP students, but also all other engineering students in the Design Clinic Program, will benefit from this activity. 
Professor John Grandin and Colorado School of Mines Professor Laura Pang (the other external reviewer) provided valuable insight regarding changes that could be made to the Design Clinic. Because engineers today often work with teams across national boundaries, the clinic should reflect the complexities of this challenge. Some of their suggestions were:

- Students could be asked to design products for the German or Japanese market and make their presentations to German or Japanese judges in their chosen language.

- A group of teams could collaborate through electronic communication methods while simultaneously working on a common design assignment. They might then present their product jointly, or separately if they decide upon variations of the product for their respective national groups.

Creating an international design clinic would reflect the realities of global business today and better prepare students for the future. It is recognized that these activities would not be simple to create and oversee. Though the students have had exposure to German and Japanese business and culture, they are far from being experts. Likewise, the faculty accustomed to design challenges from a traditional point of view would find it difficult to supervise such a multifaceted approach. International design represents a new and critical area of research and expertise. Interdisciplinary teams of engineering, business, and language/culture faculty experts will need to be created. Expanding the design clinic in this manner will help the program become more distinctive.

\section{Co-op (Internship) Experience}

The number of students participating in the IEP has increased steadily. The total number of students in the program is now more than 80 .

Issues regarding sending a group of senior American students to Japan and Germany for a period of five months to work in internship positions as engineers and researchers were of great concern to the college. Would students be able to function well in the work environment of a very different culture, especially in Japan? Would the language and culture training they received be appropriate for the challenges they were likely to face? Would this be an enriching experience for them? Would co-op employers, who invest considerable resources (in Japan, more than $\$ 5,000$ per month per student) be satisfied with student contributions?

Extensive discussions were held with many co-op employers about student performance. Results exceeded all expectations. General theme of the comments received follows:

- $\quad$ American students worked as hard and as long hours as any of our Japanese employees.

- $\quad$ They were very polite and thoughtful and fit very well in our organization's culture.

- $\quad$ Their willingness to learn our language and culture impressed us.

- $\quad$ They took initiative and asked questions.

- $\quad$ Employers felt that the students were well worth the investment. In addition to their good contribution at work, company employees learned a great deal about America through 
them. Some students in Japan even taught English language classes to company employees after regular work hours.

- While the language and culture training was adequate, more emphasis should be placed on conversation skills. (Incidentally, as a result of this input, language training was revamped accordingly.)

\section{Critical Issues for Continued Program Success}

Four critical issues for continued program success were identified. An evaluation of these issues is presented.

Funds/financial support. IEP is resource intensive. Without continued university support, this program cannot continue. Funding provided by FIPSE was most helpful to lay the foundation for the program. Since external funding cannot be assured, internal funding is, thus, essential to the stability and continuity of the program.

IEP activities should be integrated with other academic and research activities of the College so that this program further enriches other essential aspects of the College of Engineering and University mission. This also reduces the overall financial burden.

Language/Culture Training. Numerous modifications and innovations for this aspect were implemented. Another concept worth exploring is development of a set of electronic resources (especially for the Japanese program) to further augment language and culture training. This would include a multi-media approach to learning language and culture. It would involve digitizing existing slides, statistical charts and tables, graphics, and a full-motion video that focuses on various aspects of language and culture. It could serve as a meaningful electronic resource for teaching and learning language and culture.

Co-op Job Placement. The opportunity to work and live either in Japan or Germany is one of the most exciting and important aspects of the IEP. Providing this opportunity requires considerable investment by the host companies. With the economic problems in Japan and Germany, securing co-op positions will continue to be difficult. Information brochures describing the program and benefits to participating companies were updated and distributed widely. Personal contacts were made and relationships established with Japanese and German companies. Efforts were made to ensure that organizations were completely satisfied with the quality of the students placed in co-op jobs. Participant company contribution to international understanding as a result of this activity was recognized and emphasized.

Rigorous and demanding program. The way the IEP is structured in the College of Engineering at the University of Cincinnati, it is indeed an intensive and demanding program. In addition to a rigorous engineering curriculum, students must take about two years of language and culture training focusing on either Japan or Germany, maintain an honor grade average (3.0 out of 4.0), attain sufficient proficiency in Japanese or German language and culture to be able to function well in the overseas co-op job, and complete their undergraduate degree within the same time frame as other students. Consequently, only students with high aptitude and motivation should be encouraged to undertake such a program. 


\section{Summary}

The three main objectives of the International Engineering Program were met. The IEP has been fully developed, implemented, and institutionalized as a highly regarded program of the College of Engineering. Curriculum to implement language and culture training with a focus on German and Japanese has been completed. In addition to the language and culture courses with a focus on German or Japanese, various other activities were undertaken to provide students a global perspective. These activities included humanities and social sciences courses with international focus, a capstone design clinic involving international projects and companies, and a unique opportunity to live and work abroad as an intern with a company either in Japan or Germany. Some of the critical issues associated with implementing such an international engineering program, including critical issues for continued program success, are identified.

\section{Acknowledgments}

Personal interest and support of University of Cincinnati President Joseph Steger made the IEP possible. A grant from FIPSE provided the necessary resources to fully develop, implement, and institutionalize a unique international engineering program and provided an opportunity to explore innovative curriculum and language and culture training programs. The support provided by FIPSE is gratefully acknowledged.

The university-wide IEP operations committee representing other Colleges provided thoughtful comments throughout the initiation and implementation of the Program. External reviewers Professors Grandin and Pang provided helpful comments. The Intensive German Language Evaluation was done by Professor Suzanne Shipley. Ms. Gayle Elliott served as the Coordinator for the Program and Ms. Terumi Takahashi was responsible for the Japanese language and culture training and for placing students in co-op positions in Japan. CDG assisted the College of Engineering in placing students in co-op positions in Germany. The International Engineering Program could not have been successful without the extraordinary assistance provided by many faculty members, staff, and indeed without the motivation and hard work of the participating students.

\section{REFERENCES}

Pang, Laura. "A Curricular Reform and Modernization Proposal for Internationalizing Engineering Education." Colorado School of Mines, Golden Department of Global Systems and Cultures, Evaluative/Feasibility Report, Golden, Colorado, 1989.

Saikali, J.G. and R.K. Jain. An Analysis of International Engineering Programs in North America, College of Engineering, University of Cincinnati, CEAP-IEP, 96-1, 1996.

Scott, Robert. "The Challenge of Internationalization: Relating to Multi-cultural Education.” In The John Carroll University Conference Toward Internationalizing Our Curriculum, p. 27. Cleveland, Ohio, 1993.

Smickler, Ralph and Lawrence Sommers. "Internationalizing College Curriculum.” The Education Digest 54 (1989): 43-7.

RAVI K. JAIN 
Ravi K. Jain is Associate Dean for Research and International Engineering; Professor, Civil and Environmental Engineering, University of Cincinnati. He received B.S. and M.S. degrees in Civil Engineering from California State University and a Ph.D. in Civil Engineering from Texas Tech. He studied Public Adm. and Public Policy at Harvard, earning an M.P.A. degree. He has published ten books and numerous journal articles and technical reports. 